\title{
Fantasías parisienses y sastrerías londinenses. Moda, comercio y publicidad en Buenos Aires a fines del siglo XIX
}

Fantasias parisienses e alfaiates londrinos. Moda, comércio e publicidade em Buenos Aires no fim do século XIX

Parisian fantasies and Londoner tailors. Fashion, commerce and advertising in Buenos Aires' late XIX century

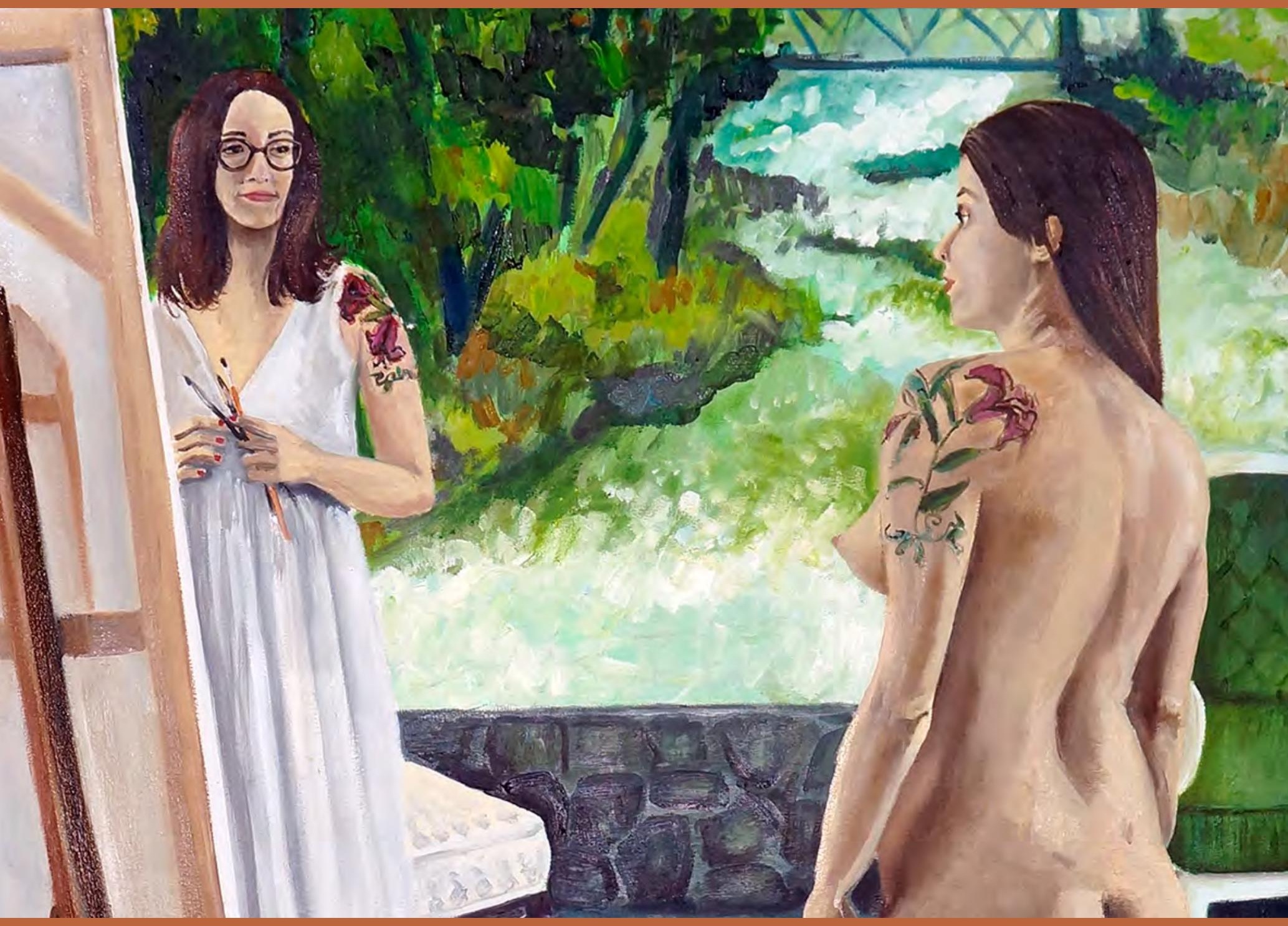




\section{María Isabel Baldasarre ${ }^{1}$}

ORCID: https://orcid.org/0000-0001-6808-6451

[resumen] Temprano en el siglo XIX, la moda y la cultura impresa se aliaron para difundir, por distintas latitudes, los últimos modelos de vestimenta producidos en París y Londres. La tienda departamental, un nuevo tipo de comercio que vendía ropa lista para usar a escala masiva, fue uno de los dispositivos que contribuyeron a esta difusión, ampliando el acceso a la apariencia burguesa. Este artículo analiza, desde las perspectivas de la historia social del arte, la cultura visual y los estudios de género, la confluencia que se produjo entre revistas ilustradas, publicidad y comercio en el Buenos Aires de fin del siglo XIX y comienzos del siglo XX. Examina la trayectoria de sus principales tiendas departamentales, sus estrategias publicitarias y la configuración del público consumidor que, en mayor o menor medida, podía concretar la atracción por esa retórica de lo nuevo impulsada por las tiendas y la prensa.

\section{[palabras clave] Comercio. Publicidad. Buenos Aires. Siglo XIX. Corset.}

[resumo] No início do século XIX, a moda e a cultura impressa forjaram uma aliança para fazer circular em diferentes latitudes os últimos modelos de roupas produzidos em Paris e Londres. A loja de departamentos, um novo tipo de comércio que vendia roupas prontas em grande escala, foi um dispositivo fundamental para essa disseminação, ampliando o acesso à aparência burguesa. Partindo da história da arte social, da cultura visual e dos estudos de gênero, este artigo analisa a associação ocorrida entre revistas ilustradas, publicidade e comércio em Buenos Aires no fim do século XIX e no início do século XX. Examinamos a trajetória de suas principais lojas de departamentos, suas estratégias publicitárias e as características de seus consumidores que, em maior ou menor medida, poderiam materializar a atração pela retórica do novo impulsionado pelas lojas e pela cultura impressa.

\section{[palavras-chave] Comércio. Publicidade. Buenos Aires. Século XIX. Espartilho.}

[abstract] Early in the nineteenth century, fashion and print culture allied to disseminate around the world the latest models of clothing that were being produced in Paris and London. The department store, a new type of commerce that sold ready-to-wear clothes on a massive scale, was key to this circulation, expanding bourgeois appearence and looks. Departing from social art history, visual culture and gender studies, this article analyzes the alliance that took place between illustrated magazines, advertising and commerce in Buenos Aires at the end of the nineteenth century and the beginning of the twentieth. We examine the trajectory of its main department stores, its advertising strategies and the features of its consumers, and how the rhetoric of the new was boosted by stores and print culture.

\section{[keywords] Commerce. Advertising. Buenos Aires. XIX century. Corset.}

Recebido em: 02-01-2019

Aprovado em: 29-05-2019

\footnotetext{
1 Doctora en Teoría e Historia del Arte, Universidad de Buenos Aires. Investigadora independiente del CONICET. Profesora regular del Instituto de Altos Estudios Sociales, Universidad Nacional de San Martín. E-mail: mbaldasarre@unsam.edu.ar. Lattes: https://www.conicet.gov.ar/new_scp/detalle.php?i$\mathrm{d}=24348 \&$ keywords=Baldasarre\&datos_academicos=yes
} 


\title{
Introducción
}

La moda fue uno de los fenómenos que más inmediatamente aprovechó de la masividad de la cultura impresa decimonónica para expandirse por todas partes del globo. Varios dispositivos contribuyeron a poner en circulación en distintas latitudes, y casi en forma simultánea, los modelos en boga en París y Londres. Las tiendas departamentales fueron uno de estos mecanismos.

Desde la historia económica, social y cultural varios autores se han ocupado de estudiar las dinámicas de producción, exhibición y consumo distintivas de estas tiendas². Caracterizadas como los monumentos espectaculares de una cultura burguesa del consumo ${ }^{3}$, en la que primaban la variedad y la opulencia, este tipo de comercio se multiplicó por el mundo imitando los ejemplos pioneros de los países centrales. La ropa lista para usar, un empleo moderno de la publicidad y la escala masiva de estos negocios inauguraron entonces un nuevo tipo de oferta que, básicamente, apuntaba a ampliar el acceso a una apariencia burguesa.

El fenómeno era tan extendido que, en 1890, un miembro incuestionable de la elite argentina como Lucio V. Mansilla ${ }^{4}$, lamentaba en sus crónicas de evocación que se hubiera perdido la posibilidad de identificar la procedencia de un "tipo humano" a partir de su vestimenta:

\begin{abstract}
Actualmente el mismo cuello, el mismo calzado, el mismo pantalón, el mismo saco, jaquet, levita ó frac, salen de las tiendas de Londres, de París, de Berlín, de Madrid, de Roma, de Viena, de San Petersburgo y para distinguir la nacionalidad de los que los llevan es necesario fijarse en su tipo, ó sea en los rasgos característicos de la fisonomía [...] En América, el fenómeno estaba regido por las mismas leyes; y actualmente todo el mundo se viste poco más ó menos del mismo modo, tanto que algunos, -hablaremos de nuestra propia tierra para que nos entendamos mejor-, de los que van á París, suelen volver de allí vestidos con menos gracia ó peor de lo que se vestían acá. (MANSILLA, 1890, V, p. 48-49)
\end{abstract}

En sus palabras, la posibilidad de lucir ítems de vestimenta semejantes se había extendido a lejanas capitales como Buenos Aires, pero además se había esparcido entre los diversos sectores sociales. Como se verá a continuación, las grandes tiendas erigieron una clientela que rebasaba los sectores altos para atraer a las capas medias que, gracias al precio fijo, a las liquidaciones y a los saldos podían ahora tener la posibilidad de renovar su guardarropa con prendas ya confeccionadas.

\footnotetext{
2 Son estudios pioneros en la materia los trabajos de Miller (1981), Perrot (1994) y Rappaport (2001).

${ }^{3}$ El siglo XIX se distinguió precisamente por la adhesión de grandes sectores de la población a los parámetros de vestimenta marcados por la burguesía, que se hicieron extensivos incluso a sectores medios que los emulaban para distanciarse de la clase trabajadora (PERROT, 1994, p. 8). Ante este proceso de uniformidad de la apariencia burguesa, las marcas de clase quedaban reservadas a los detalles: los cortes y calidades de las telas, la blancura de las camisas y los accesorios como sombreros, bastones, relojes o pieles (GARB, 1998, p. 35).

${ }^{4}$ Lucio V. Mansilla (1831-1913) fue un general del Ejército, miembro de elite y sobrino del gobernador de Buenos Aires Juan Manuel de Rosas. Se destacó también como periodista, escritor, político y diplomático. Sus obras literarias se caracterizaron por ser relatos coloquiales llenos de anécdotas y diálogos que captaban con lucidez las percepciones de los miembros de su clase.
} 
Paralelamente al establecimiento de las tiendas, una floreciente cultura impresa transformó al consumo, a la moda y a la indumentaria en cuestiones de interés público. Este atractivo por las cuestiones de moda se registró tanto en la prensa especializada como en los diarios masivos orientados al gran público. Kate Nelson Best (2017) en su estudio sobre el periodismo de moda demuestra cómo, muy tempranamente, las primeras revistas del rubro establecieron un vínculo entre la industria y el lenguaje de la moda, gestándose un acuerdo entre publicaciones, proveedores y negocios.

Excediendo el panorama europeo, las revistas ilustradas en general, y las femeninas en particular, tuvieron un rol primordial en la internacionalización de imágenes, consejos y patrones gratuitos sobre moda. Es decir, la prensa fue un actor central en el éxito de estos comercios, al establecerse un diálogo fluido entre lo que las tiendas y las publicaciones exhibían y volvían deseable, y lo que estas mismas instancias hacían posible. Tal como señala Erika Rappaport en la cultura del consumo propuesta por las tiendas departamentales "leer, mirar y comprar" configuraban un mismo "trayecto metropolitano" (RAPPAPORT, 2001, p. 111). Los vestidos se admiraban en los maniquíes de los negocios y en los figurines y publicidades de las revistas -los reclames como se decía entonces- que proporcionaban las direcciones y precios de dónde conseguirlos ya hechos, así como los moldes y los insumos para su confección casera. A medida que avanzó el siglo estos compromisos se hicieron cada vez más explícitos. Las revistas fueron invadidas por publicidades visualmente atractivas, e incluían cupones o concursos que otorgaban prendas como premios. Así, se terminaba vinculando de modo directo a los dos sostenedores materiales de las publicaciones: los anunciantes (los comercios) y los suscriptores (sus clientes).

Este artículo se propone reconstruir y analizar las particularidades del surgimiento de las grandes tiendas departamentales en Buenos Aires ${ }^{5}$ y el uso que éstas hicieron de la publicidad en las revistas ilustradas. Hasta el momento, la historia de estas tiendas es terreno poco explorado, sobre el que se repiten siempre los mismos datos. Las historias de la moda con las que contamos hacen una reconstrucción anecdótica de su devenir, sin un trabajo documental exhaustivo ni un análisis detenido de su retórica visual ${ }^{6}$. Por otra parte, trabajos recientes se han ocupado del vínculo entre socialización, producción y consumo pero sin hacer eje ni en las representaciones ni en su dimensión visual ${ }^{7}$.

Desde la perspectiva de la historia cultural y del arte, y la llamada cultura visual ${ }^{8}$, busco examinar las estrategias discursivas y visuales elaboradas por estas tiendas en pos de configurar y captar nuevos clientes. En este sentido, este trabajo se vincula con estudios

\footnotetext{
${ }^{5}$ Para ånel caso de Santiago de Chile véase el riguroso análisis de Jacqueline Dussaillant Christie (2011). Por su parte Marissa Gorberg (2013) se ha centrado en el caso específico de la tienda carioca Parc Royal.

${ }^{6}$ Por ejemplo: SAULQUIN, Susana. La moda en la Argentina. Buenos Aires: Emecé, 1990.

Véase Fernando Rocchi (2006), capítulo 2. Para el periodo inmediatamente posterior al que aquí se analiza, véase Donna J. Guy (2017).

${ }^{8}$ Los estudios visuales proponen discutir el tema de la imagen visual sin insistir en su valor estético, por fuera de la jerarquía de las bellas artes. Uno de sus principales aportes consiste en problematizar las prácticas de producción de significado cultural a partir de la visualidad. Entre los principales autores véanse: Mirzoeff (2003), Moxey (2003), Mitchell (2009) y Brea (2006).
} 
como los de Sandra Szir, Laura Malosetti Costa, Claudia Román, Lía Munilla Lacasa y Georgina Gluzman quiénes han analizado la cultura gráfica en la Argentina del siglo XIX, en el cruce entre sus condiciones materiales y técnicas de posibilidad, las especificidades locales y la visualidad global de la época ${ }^{9}$. Asimismo, mi mirada dialoga con trabajos que investigan y tensionan las representaciones del género en el período como el de Margaret Beetham (1996) que se aproxima a las revistas femeninas y sus imágenes entre la popularización de la cultura impresa y las políticas del género, y el de Tamar Garb (1998) que desmonta la construcción de la diferencia sexual en los cuerpos altamente normalizados del siglo XIX. Por otro, los análisis de la denominada fashion theory también son referencias productivas para el enfoque aquí propuesto.

La hipótesis que recorre las páginas que siguen sostiene que los comercios no hicieron simple uso de recursos publicitarios que los antecedían, sino que estos mecanismos visuales se produjeron en simultáneo y fueron configuradores de la cultura del consumo que primó en ellos ${ }^{10}$. Sostengo asimismo que la ocularidad, práctica central para el sistema de la moda, ostentó un lugar más que significativo en el proceso de compra y venta desarrollado por estos negocios. Tanto tiendas como publicidades participaron de aquella "tendencia moderna a plasmar en imágenes o visualizar la existencia" (MIRZOEFF, 2003, p. 23), en consonancia con las aspiraciones de modernidad que Buenos Aires, como nueva metrópolis, ostentó a fines del siglo XIX. Además, las publicidades no sólo fueron funcionales a los productos ofrecidos a la venta, sino que constituyeron representaciones complejas que aportaron a las concepciones hegemónicas respecto de cómo debían verse hombres y mujeres, en tanto cuerpos altamente generizados que eran "expresión de las normas sociales" (GARB, 1998, p. 11). Es decir, en los modos en que hombres, mujeres y niños fueron retratados por los avisos se condensaron tópicos que excedieron la mera intención de los comercios por vender, para hacer visibles construcciones canónicas sobre la clase, el género y el lugar del consumo y la moda en dichas identidades.

\section{Vidrieras del consumo: las tiendas departamentales}

Las grandes tiendas departamentales comenzaron a instalarse en Buenos Aires hacia el último cuarto del siglo XIX. Treinta años después se habían expandido a un ritmo inusitado. Para inicios de 1870 lo que abundaba eran los baratillos, roperías y depósitos, es decir tiendas económicas que vendían ropa, nueva y usada, a bajo precio. Además, existían miembros de la elite o comerciantes que traían remesas de sus viajes a Europa. A su regreso, los avisos en la prensa anunciaban los remates de telas, camisas, calzones, chales y pañuelos, en general ofrecidos al por mayor para tenderos, roperos y zapateros. En algunos casos también eran

\footnotetext{
${ }^{9}$ Véanse los artículos que debaten estas cuestiones en el libro de compilado por Laura Malosetti Costa y Marcela Gené en 2009 que se cita en la bibliografía.

10 Al respecto Lori Anne Loeb ha estudiado la publicidad dirigida a las mujeres en la Inglaterra victoriana, en el cruce entre el boom de las tiendas departamentales y la expansión de la prensa ilustrada. Véase Loeb (1994).
} 
accesibles para aquellos porteños ${ }^{11}$ que no tenían la posibilidad de comprar en el extranjero pero que querían usufructuar de la distinción y glamour que connotaban estos productos.

El relevamiento, todavía en curso ${ }^{12}$, nos revela que para 1880 había en Buenos Aires al menos cinco grandes comercios de indumentaria (que tenían varios departamentos de moda femenina, masculina e infantil). En 1890 este número ascendía a ocho, mientras en 1905 eran más de veinte los grands magasins que ofrecían ropa "lista para usar" y objetos diversos en sus departamentos de sastrería, bonetería, mercería, zapatería, perfumería, etc. Sin embargo, no es solo que los negocios se multiplicaron, sino que algunos adquirieron proporciones megalómanas en sus metros cuadrados de superficie, en la cantidad de empleados y empleadas y en los índices de facturación.

La más antigua de estas grandes tiendas fue a $A$ la ciudad de Londres. Abierta al público en marzo de 1873 pero renovada en 1899 con una impactante obra que ocupaba un cuatro de manzana, el edificio se volvió el ícono repetido en las publicidades del período. Los avisos refrendaban que se trataba de la primera casa de Buenos Aires en establecer el sistema de ventas a precio fijo, y que era la "tienda más vasta y mejor surtida de Sud-América"13. Sus dueños eran dos franceses, los hermanos Juan e Hipólito Brun, llegados a Buenos Aires en 1867 y 1869 respectivamente. Con poco capital económico, pero con el plus de haber trabajado siete años como empleado de las emblemáticas tiendas del Bon Marché en París, Juan se acomodó rápido entre el comercio francés local, incitando a su hermano a cruzar el Atlántico para abrir un negocio propio. A menos de quince años de su inauguración, la casa tenía ciento doce empleados internos (que trabajan en la tienda) además de cien externos, la mayoría de ellos franceses, que se encargaban de proveer costuras y bordados (GALARCE, 1887, p. 526-527). Tres tílburis a cuatro ruedas ofrecían el servicio de repartición a domicilio para las mercaderías vendidas en 1887 por más de un millón de pesos, aproximadamente el equivalente a 23 millones de dólares en $2015^{14}$. Cuatro años después la empresa tenía doscientos empleados que se repartían en los talleres de confecciones, depósitos, embalaje, gabinetes de prueba, ascensores, cocina y comedor para el propio personal. Se habían sumado también dos coches más para la distribución de mercaderías. Para la mayor parte de su producción la tienda recurría a operarios exclusivos radicados en Buenos Aires mientras que las telas provenían de los principales centros de fabricación y distribución como París, Londres o Lyon ${ }^{15}$. Al promediar la primera década del siglo XX, el número de empleados se había casi cuadriplicado: 450 hombres y 250 mujeres, al ritmo de sus ventas que tenían "proporciones fabulosas" (MARTÍNEZ, 1904, p. 79).

\footnotetext{
11 Porteño/porteña es el gentilicio utilizado para los habitantes de Buenos Aires.

12 Actualmente me encuentro confeccionando una base de datos de los comercios de moda e indumentaria de Buenos Aires en el período 1870-1915 a partir los datos provistos por la prensa periódica, las guías comerciales y de viajeros, los censos y otras fuentes de época.

13 Para un primer acercamiento sobre las publicidades de $A$ la ciudad de Londres, véase el artículo reciente de Moreyra y Garabana (2019).

${ }^{14}$ Las equivalencias a los montos actuales se han realizado utilizando el site: http://ww. historicalstatistics.org/Currencyconverter.html. Acceso en: Junio 2019.

15 A la ciudad de Londres. Álbum ilustrado de la República Argentina. Periódico quincenal con vistas y retratos, 1 jul. 1891.
} 
Sin embargo, A la ciudad de Londres tenía varias competidoras, entre ellas El Progreso, establecida en 1875, que se jactaba precisamente de ser la más "elegante y mejor surtida de la capital". La tienda era resultado de la unión de varios establecimientos previos que tenía en Buenos Aires su fundador y administrador: el francés Juan Bautista Burnichon y fue comandada, a partir de 1890, por su hijo Eugenio ${ }^{16}$. Gran parte de su surtido era recibido de Europa, pero contaba también con talleres especiales para la confección "sobre medida" lo que abarataba los costos al ser realizada con "mano de obra del país". No nos olvidemos que la principal estrategia comercial de estas tiendas, al igual que sucedía con sus pares europeas, residía en obtener una escasa ganancia de una inmensa cantidad de ventas (PERROT, 1994, p. 59). Para 1891 también registraba doscientos empleados ${ }^{17}$.

Las más nueva era A la Ciudad de México, también fundada por dos franceses quiénes primero habían sido dependientes de comercio: Albert Ollivier y Joseph Albert. Abierta en 1888 seguía el modelo marcado por el Bon Marché parisino. Poseía un impactante inmueble en la zona céntrica de la ciudad, que aparecía como recurso icónico en sus avisos publicita$\operatorname{rios}^{18}$. El incluir las fachadas de los comercios en los avisos actuaba tanto como un símbolo de progreso como de la posibilidad de satisfacer cualquier deseo a través de la abundancia de su oferta (LOEB, 1994, p. 53). La tienda fue reconstruida en 1908, en el escaso término de un año, luego de un fatal incendio. Se trataba de un edificio de cinco pisos con ascensores que alojaba a sus más de veinte departamentos, y era celebrada por estar a la altura de los "refinamientos de nuestro mundo elegante, exigente como el que más en materia de vestir y de vestir bien, con arreglo á la última palabra de la moda"19.

Tanto A la ciudad de Londres como El Progreso referían a sus casas de compras en "Londres, París, Lyon y Manchester" reforzando así la idea de aquella geografía en dónde se diseñaba y confeccionaba la moda masculina y femenina y los sitios que proveían las telas más exquisitas para su realización. Los tres comercios se encontraban en un radio de 300 metros unos de los otros, y además estaban muy cerca del centro cívico y político de la ciudad: la Plaza de Mayo. A través de la proveniencia de sus dueños, sus vendedores y sus productos, estos tres negocios corporizaban en Buenos Aires la "mitología de París" como centro de la moda femenina (NELSON BEST, 2017, p. 51; STEELE, 1998).

No obstante, la sastrería masculina seguiría fuertemente asociada con Inglaterra, más específicamente con el west end londinense. Así varias otras casas, como Gath y Chaves (fundada en 1883) y James Smart (en 1888) ambas ubicadas a comienzos de siglo en Bartolomé Mitre y Florida, por sólo mencionar dos de las más emblemáticas, aludían a la posibilidad de comunicarse en inglés con su clientela y ser capaces de acercar a los porteños exclusivos sombreros o zapatos con sello británico.

\footnotetext{
${ }^{16}$ Eugenio Burnichon (1869-1936), hijo de Juan Bautista Burnichon (ca. 1833-1890) y Noemí Chapon, nacido en Buenos Aires.

17 Tienda El Progreso. Álbum ilustrado de la República Argentina. Periódico quincenal con vistas y retratos, 15 agosto 1891 , p. 102-103.

18 Véase Caras y Caretas, n. 144, 6 jul. 1901.

19 Para las damas. Notas de elegancia. El Hogar, 30 sept. 1908.
} 
Fundada por el escocés Alfredo H. Gath, arribado en 1872 y por el argentino Lorenzo Chaves, quien tenía experiencia en el "ramo de la pañería", esta firma llegó a transformarse en un verdadero emporio. Su búsqueda por monopolizar los pequeños comercios era registrada con cierto temor por las guías de viajeros como la Baedeker de 1904, que comparaba su expansión con una suerte de movimiento depredador: “cada día se extiende más, como un pólipo, agarrando y desalojando con sus largos tentáculos, todos los pequeños negocios situados en las proximidades" (MARTÍNEZ, 1904, p. 79). La tienda estaba más orientada a la clientela masculina si tenemos en cuenta que, hacia 1903, de sus 551 empleados 496 eran hombres y 55 mujeres. Ese año, las ventas habían alcanzado un promedio de 7.200.000 millones de pesos $\mathrm{m} / \mathrm{n}$, una cifra nada desdeñable si tenemos en cuenta que equivalía a unos a 79 millones de dólares actuales. En 1908 la firma fue transformada en Sociedad Anónima y al año siguiente registraba - en todas sus sedes - tres mil empleados. Para 1910, uno de los grandes libros lanzados en ocasión del Centenario para exhibir al mundo los progresos obtenidos por la Argentina, la ubicaba en lo más alto del comercio local e incluso regional: Gath y Chaves tenía sucursales en las principales ciudades del país como Rosario, Paraná, Córdoba, Mendoza, La Plata, Tucumán, Mercedes y Bahía Blanca, una filial en Santiago de Chile y una casa de compras en París. Sus catorce departamentos cubrían los ramos más diversos de la toilette femenina, masculina e infantil, así como muebles y todo lo necesario En suma, para la primera década del nuevo siglo el centro de Buenos Aires, urbe que estaba creciendo al ritmo inaudito de la llegada de millares de inmigrantes ${ }^{20}$, tenía un buen surtido de comercios que ofrecían un nutrido stock de productos de vestir, renovado cada estación. Estas tiendas eran responsables de proveer a sus sectores altos y medios de los productos imprescindibles para hacerlos sentir "modernos" y partícipes de los nuevos rituales del consumo. La publicidad ilustrada cumplió un rol central en todo este proceso.

\section{Volver visual el deseo: las publicidades}

Al ritmo del crecimiento y la profesionalización de estos comercios, la publicidad ganó lugar, tanto material como simbólico, en las propias revistas, volviéndose más sofisticada y dejando las últimas páginas para dialogar - mano a mano - con artículos y editoriales (BEETHAM, 1996, p. 142-144). Estas nuevas retóricas de la imagen publicitaria no sólo fueron elaboradas y utilizadas por las tiendas departamentales, sino que también sastrerías y sombrererías hicieron uso de ellas. Los avisos fueron los principales difusores de la novedad visual, el nuevo lugar dónde ilustrar, y a la vez promocionar, los últimos modelos de fracs, vestidos y sombreros. De este modo, los avisos del fin de la centuria enfatizaron, cada vez más, la equivalencia entre lector y consumidor.

Este proceso no fue específico de los ítems de moda, pero sin duda encontró en ellos piezas ideales a ser reproducidas y volverse objetos de deseo, es decir, la retórica de lo nuevo alimentó tanto a las prendas de vestimenta como al proceso de la publicidad que fomentó su

\footnotetext{
20 En 1895 la ciudad de Buenos Aires tenía 663.854, habitantes de los cuáles 1.231.698 eran extranjeros, es decir el 52\% de ellos. En 1909 el total de pobladores de la ciudad era de 1.311.100 y un 45,6\% de ellos eran extranjeros.
} 
consumo. Al finalizar la temporada, las reducciones de los precios eran el mecanismo usual para terminar con las existencias de la estación que concluía. Las publicidades buscaban incitar al gasto y para eso fomentaban la idea de que era necesario, y atractivo, reemplazar las prendas pasadas de moda por otras nuevas.

Así las palabras "novedad", "París", "Londres", "barato", "precios módicos”, las alusiones a la rapidez con que las prendas llegaban al país o se adaptaban a la corporalidad de sus usuarios se repetían incesantemente en los textos que acompañaban estas publicidades.

Para las décadas de 1870, los almanaques, guías y revistas eran claros testimonios del modo en que la publicidad sintetizaba la información de los productos que las tiendas ofrecían en venta. Básicamente se trataba de avisos tipográficos, dónde la imagen tenía nula o escasa presencia. Si ésta aparecía era generalmente en la forma de clichés genéricos como por ejemplo un cordero para referirse a una casa que se especializaba en ropa de lana o una galera para una sombrerería - y no aportaba información específica sobre los objetos disponibles (figura 1). Los reclames participaban así de ese "universo visual compartido" entre Europa y América en que la apropiación y la reutilización de clichés eran mecanismos habituales de la cultura gráfica decimonónica (MUNILLA LACASA; GLUZMAN, 2016, p. 32).

\section{FIGURA 1 - AVISO DE AU MERINOS, ALMANAQUE PARA LA FAMILIA. MODAS Y NOVELAS ILUSTRADAS.}

BUENOS AIRES, F. LAJOUNE ÉDITEUR, 1880

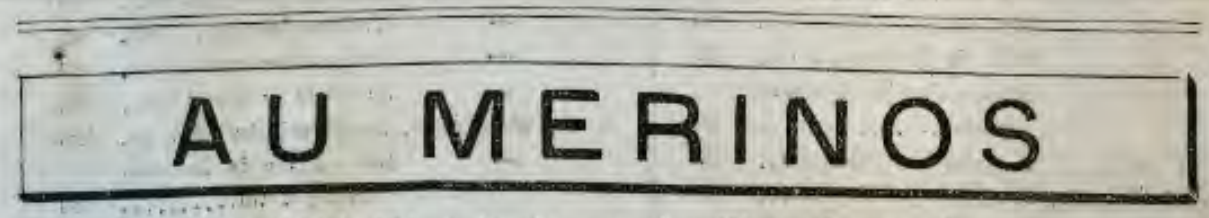

104, Rivadavia, esquina Ghacabuco, 2

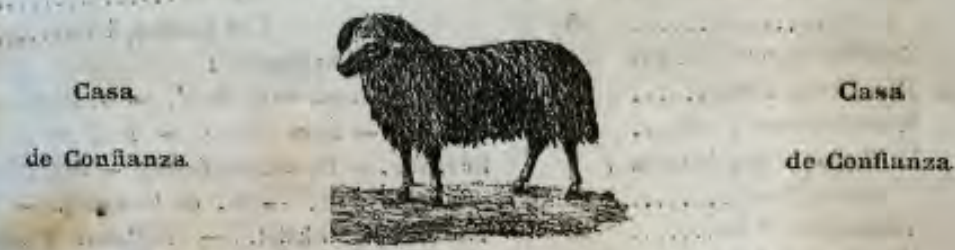

*-a. GRIN SURTIDO DE ARTICLLOS DE LANA

Boneteria de todas clases-Ropa blanca-Lenceria dè Mesa

Dist FIAZADAS SEDA, LANA Y ALGODON

Sabanas y Fundas hilo y Álgodon

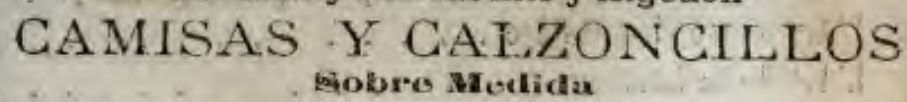

sobres Mudida

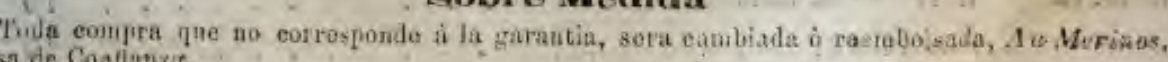
easa de Coatianzit,

104, Rivadavia, esquiua Chacabuco, 2

FUENTE: BALDASARRE, María Isabel. Biblioteca Nacional Mariano Moreno. 
Lo que registramos en la imagen publicitaria va a ser proceso de ida y vuelta, es decir los avisos comenzaron a incorporar construcciones visuales más complejas y a hacer guiños a los modos locales para adquirir los productos, pero también persistieron aquellos limitados a los recursos textuales. Por ejemplo, en 1878 una propaganda de la sastrería Au Bon Marché muestra tres elegantes caballeros luciendo sus trajes de calle y noche, delante del comercio (figura 2). Es evidente la voluntad por hacer familiar el local a los consumidores porteños, al recrear su vista urbana y los adoquines característicos de las calles del centro de la ciudad, en este caso Cangallo. Reforzando esta idea, se incluye un diálogo entre los tres casuales "modelos" que dice: "Mirá, che que bien vestido anda aquel señor", incluyendo la interjección coloquial "che", referencia indiscutida al uso del lenguaje español en el Rio de la Plata, mientras el segundo agrega: "Y con qué elegancia! Daría mucho por conocer su sastre", y el elegante responde: "Señores, si quieren elegante y barato vayan a la sastrería Au Bon Marché”.

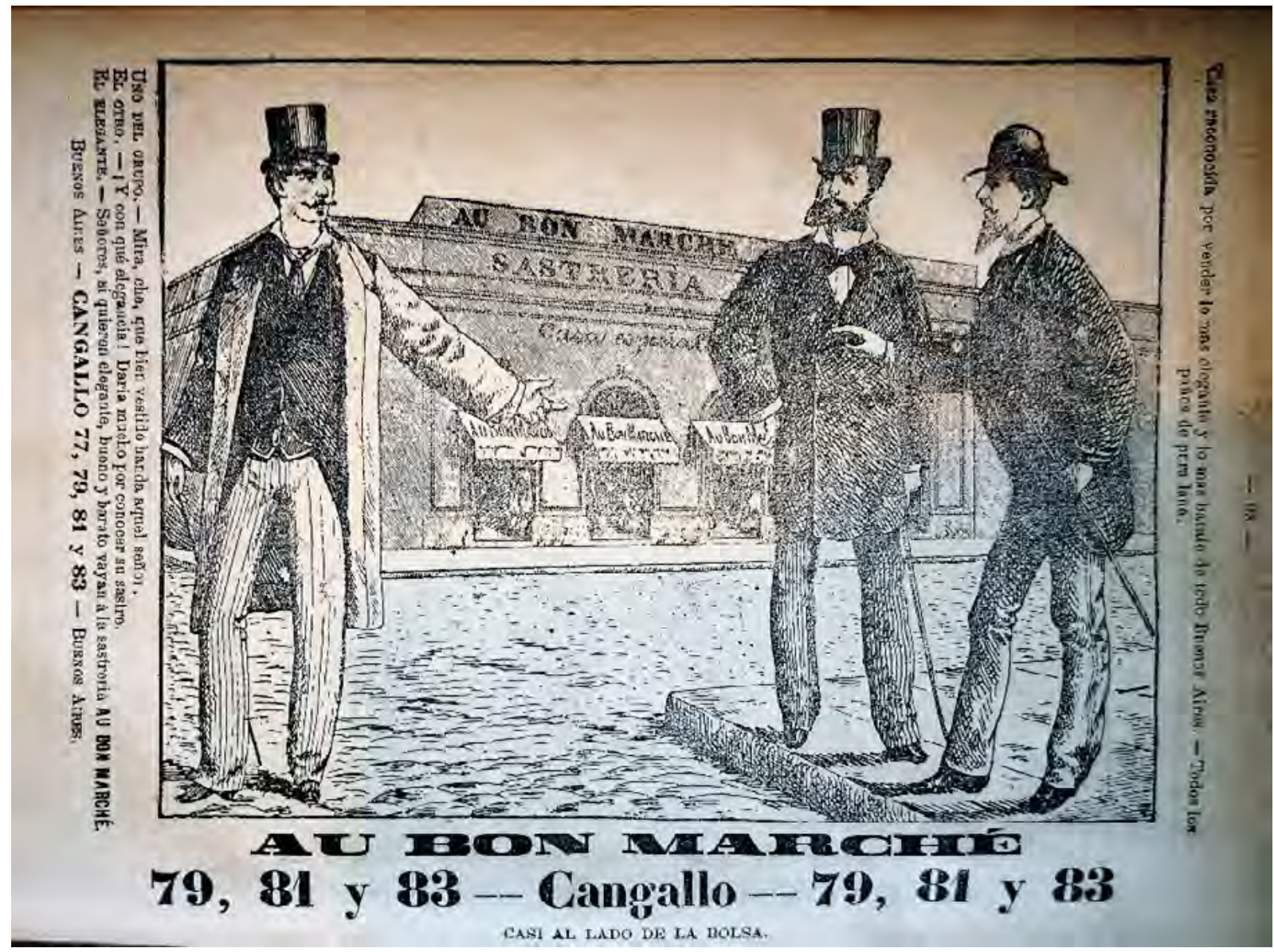

FUENTE: BALDASARRE, María Isabel. Biblioteca Nacional de Maestros.

En 1880 ya encontramos publicidades que incluyen información visual detallada sobre las prendas. Por ejemplo, la casa P. Dupont ofrecía "trajes confeccionados para hombres, 
jóvenes y niños" y la imagen mostraba seis figurines - tomados sin duda de clichés de revistas importadas - que remitían a la elegancia y decoro con que el género masculino podía vestirse acorde a las distintas edades y horas del día. La confección era exclusivamente francesa, y la casa contaba con oficiales para adaptar los envíos a cualquier persona en el lapso de dos horas ${ }^{21}$.

Ese mismo año también nos topamos con un caso en el que es notable la satirización que la publicidad produce en relación con los cambios de la moda (figura 3). Así dos avisos de A la Ciudad de Londres comunican, mediante reproducciones de planchas importadas, que la casa se especializa tanto en la "moda de ayer" representada por un figurín de Bertall que bien podía representar un modelo del célebre Frederick Worth como en la "Moda del mañana". Realizado por el dibujante Faustin, el vestido del futuro era un osado modelo - que acertaba en su poder anticipatorio- y dejaba entrever gran parte del busto y de las piernas de la muchacha. El epígrafe rezaba: "Vestido á la Nana!" en alusión de la célebre prostituta de la homónima novela de Émile Zola publicada ese mismo año. El público de Buenos Aires debía así estar al tanto de las últimas novedades literarias para captar el sentido de la chanza: las connotaciones sexuales de los cambios de una moda que se iría minimizando para dejar, cada vez más, el cuerpo al descubierto.

\section{FIGURA 3 - AVISO DE A LA CIUDAD DE LONDRES, ALMANAQUE DE LA FAMILIA. MODAS Y NOVELAS ILUSTRADAS. BUENOS AIRES, F. LAJOUANE, ÉDITEUR, 1880}
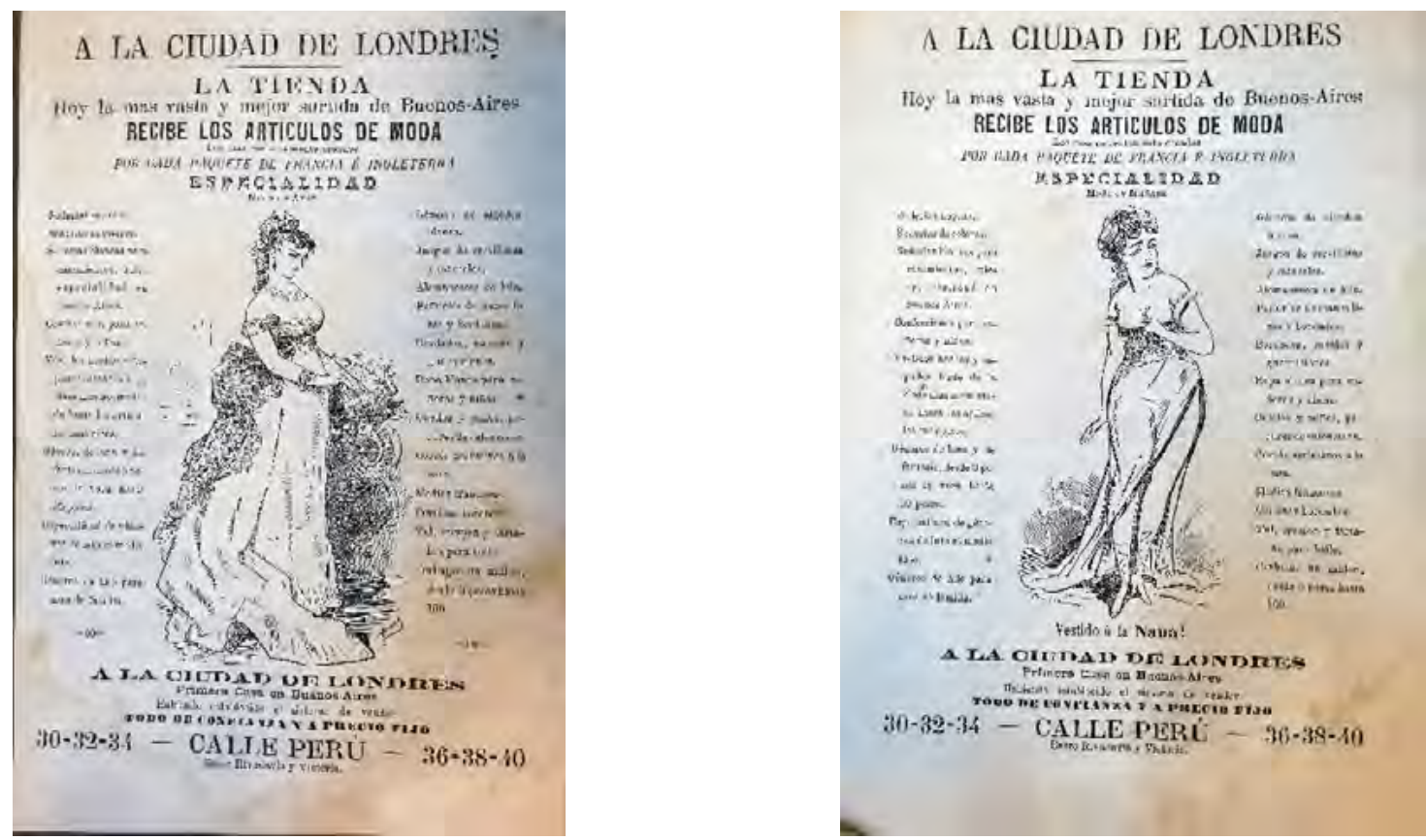

FUENTE: BALDASARRE, María Isabel. Biblioteca Nacional Mariano Moreno.

21 Aviso de P. Dupont, trajes confeccionados. Almanaque de la familia. Modas y novelas ilustradas. Buenos Aires: F. Lajouane Éditeur, 1880. 
La alusión al humor como recurso publicitario era una tradición que tenía sus antecedentes en la década previa dónde el principal periódico satírico de la ciudad, El Mosquito, venía haciendo uso de varias estrategias para promocionar a sus sostenedores regulares como A la ciudad de Londres o la sombrerería Perissé. Usufructuando de la rapidez y sagacidad de sus dibujantes, el periódico incluyó avisos ilustrados que anunciaban el traslado de un local o el arribo de un cargamento desde Europa y, en un mecanismo más sofisticado, aprovechó de las humoradas políticas para insertar allí las referencias a los comercios de modas (ROMÁN, 2017, p. 131 y 142). Así sucedió por ejemplo en ocasión del sitio de Buenos Aires de $1880^{22}$, dónde una muchacha aclaraba que había comprado como provisiones cuatro sombreros, seis vestidos y dos docenas de guantes en A la Ciudad del Londres mientras el hombre de la viñeta contigua avisaba a su atribulada mujer que no tendría inconvenientes en salir a las calles ya que su galera resistía los bombardeos porque había sido comprada en lo de Perissé (figura 4).

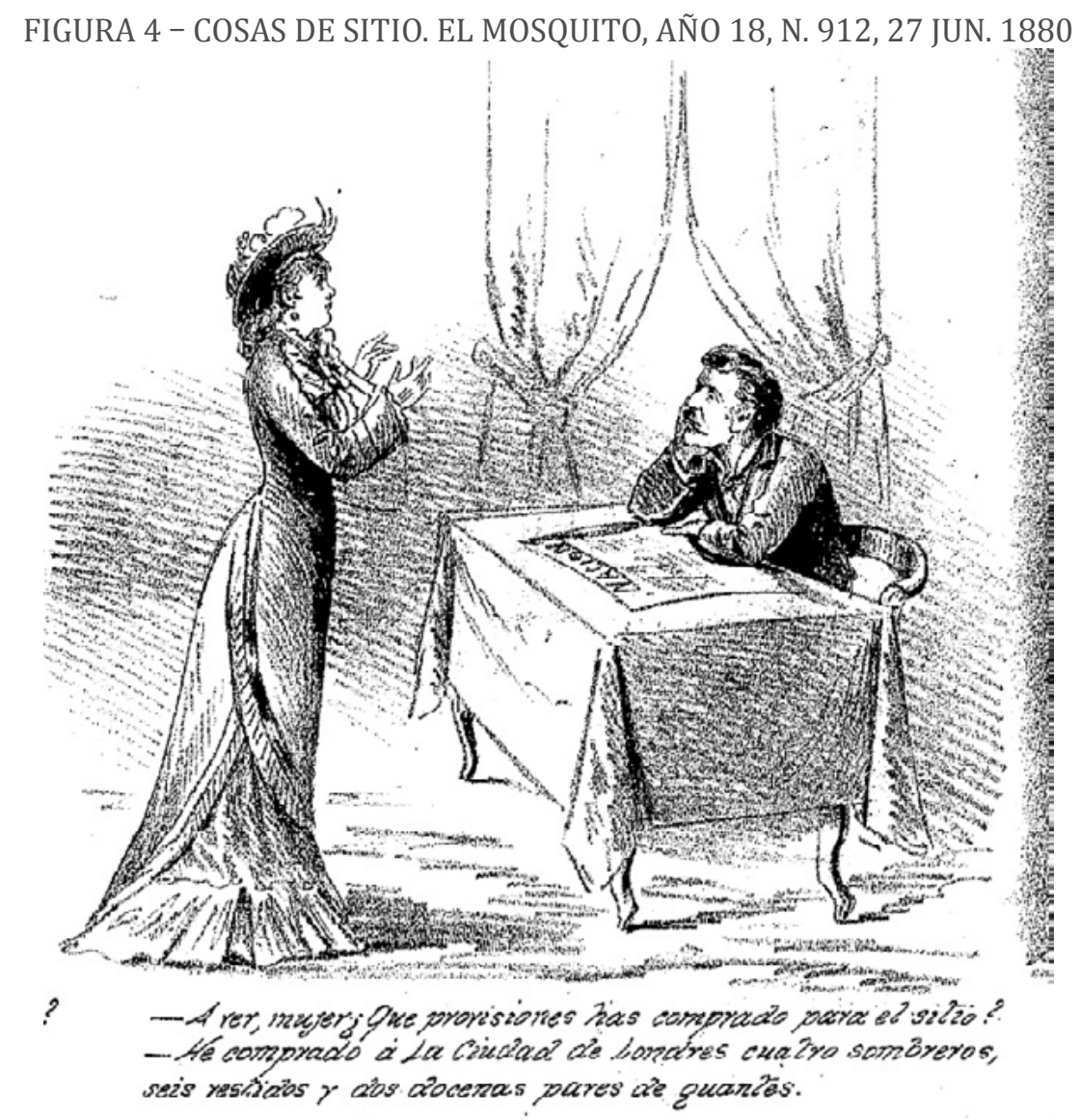

FUENTE: Biblioteca Nacional Mariano Moreno.

\footnotetext{
22 En junio de 1880 se produjeron, en las calles de Buenos Aires, conflictos armados entre fuerzas de la Provincia de Buenos Aires y el Estado central, con la participación de civiles y militares. El enfrentamiento culminó con el triunfo del poder nacional y el nombramiento de Buenos Aires como capital federal.
} 
También recurriendo al chiste gráfico, el semanario Caras y Caretas inició una tradición de viñetas satíricas orientadas a la venta de productos de vestimenta. El recurso al humor y las refinadas tácticas para la venta no son casuales si tenemos en cuenta que en su staff la publicación contaba con eximios dibujantes que llenaban sus páginas con complejas caricaturas de personajes públicos. Además, Caras y Caretas fue probablemente la revista que en el cambio de siglo más experimentó y utilizó todos los formatos y recursos disponibles de la cultura gráfica en su búsqueda por volverse atractiva y ofrecer modernidad a sus lectores (SZIR, 2011, p. 71-72). Por ejemplo, una publicidad de la Fábrica de Tejidos San Carlos exhibía a dos caballeros con galera, excepto que uno estaba en ropa interior. A la pregunta de su compañero de cómo tiene el valor de "andar en ropas menores": el otro le responde: "Porqué cuándo hay calor estas vienen igual o mejor que las ropas exteriores” (figura 5).

\section{FIGURA 5 - AVISO DE SAN CARLOS. GRAN FÁBRICA DE TEJIDOS DE PUNTO, CARAS Y CARETAS, AÑO 1, N. 3, 22 OCT. 1898}

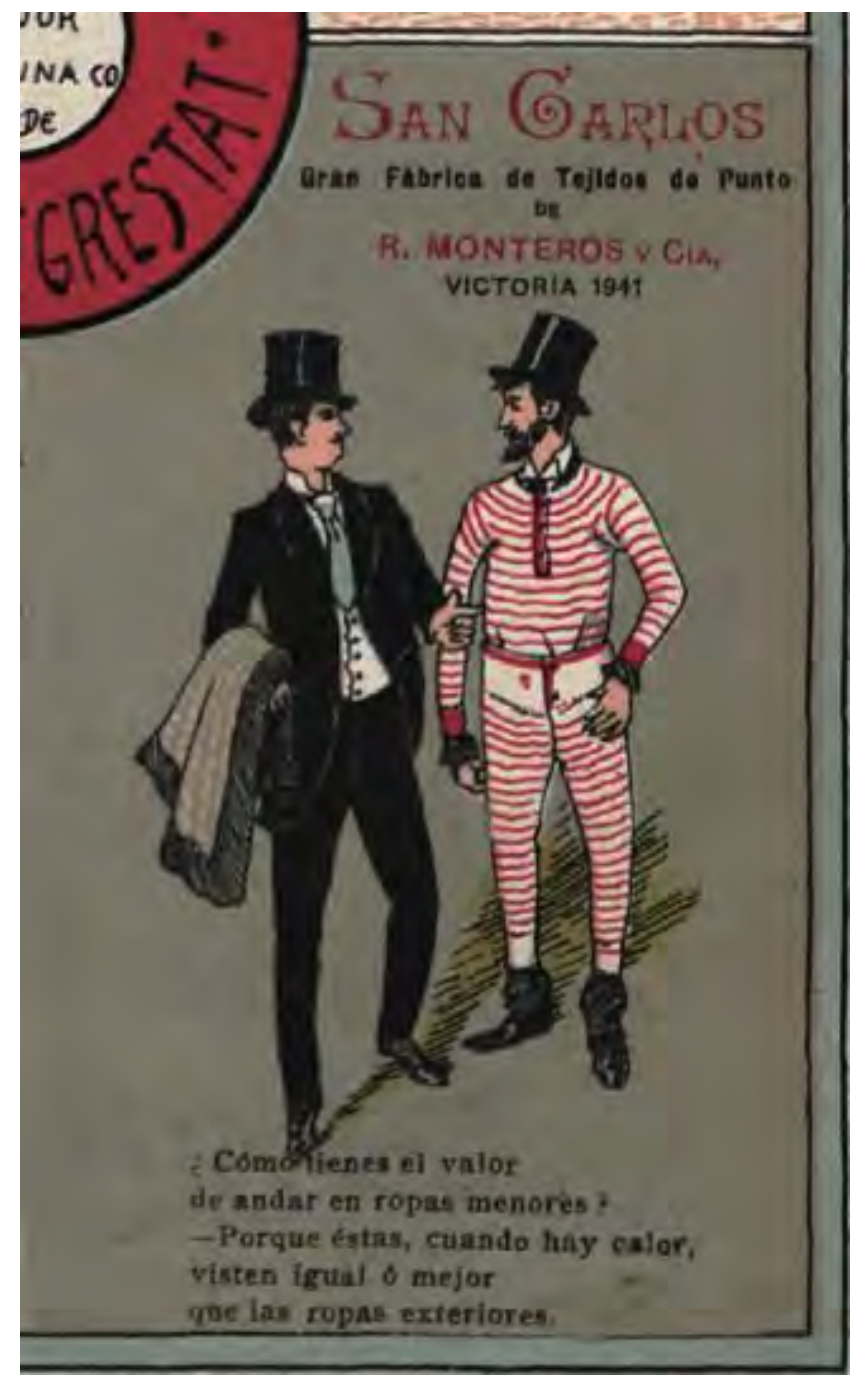

FUENTE: Biblioteca Nacional de España. 
Eduardo Sojo, uno de los principales caricaturistas políticos que tuvo Buenos Aires hacia el fin del siglo XIX, también hizo uso de las posibilidades económicas que le brindaba la publicidad, poniendo su pluma y sus recursos humorísticos a disposición de comercios como El Palacio de Cristal, para las publicidades de la revista La Mujer ${ }^{23}$. En el aviso, una mundana joven sentenciaba a su pretendiente que prestaría atención a su "cariño" cuándo estuviese conveniente vestido por dicha sastrería.

Es decir, las publicidades buscaban ampliar el espectro de su público recurriendo a la parodia y al ingenio, pero a la vez cristalizaban los nuevos valores asociados a estas inéditas prácticas de consumo, en estos casos: la especialización y calidad que habían adquirido las ropas blancas (interiores) y la relevancia de la apariencia para convertirse en un "candidato" apetecible.

Volviendo a los ejemplos no explícitamente humorísticos, la publicidad de sastrería La Moda de Augusto Scharwz, incluida en el Almanaque Peuser de 1899 presentaba una sofisticada construcción en relación con los procesos de distinción y uniformidad y la retórica tecnológica asociada a la moda (figura 6). La imagen muestra dos grupos masculinos unidos en su centro por una máquina de vapor que proveía el "nuevo sistema para vestir trajes a la minuta". Por un lado, hombres reales de carne y hueso se agolpan para sumergirse en la máquina, dispuestos a pagar lo necesario. Llevan barrigas prominentes, en su mayoría lucen el bombín o la gorra característica del hábito diario. En la escalera, un personaje viste la indumentaria distintiva del gaucho argentino. Por el lado izquierdo de la imagen los personajes emergen como elegantes figurines de revistas de moda o publicidad, civilizados, luciendo moderna ropa de etiqueta, en su mayor parte con galeras y bastones. Sobre ellos, dos obreros con la boina y ropa de trabajo alimentaban esta increíble máquina de transformación.

\section{FIGURA 6 - AVISO DE SASTRERÍA LA MODA. ALMANAQUE PEUSER PARA EL AÑO 1899, AÑO 12, BUENOS AIRES, PEUSER, 1898}

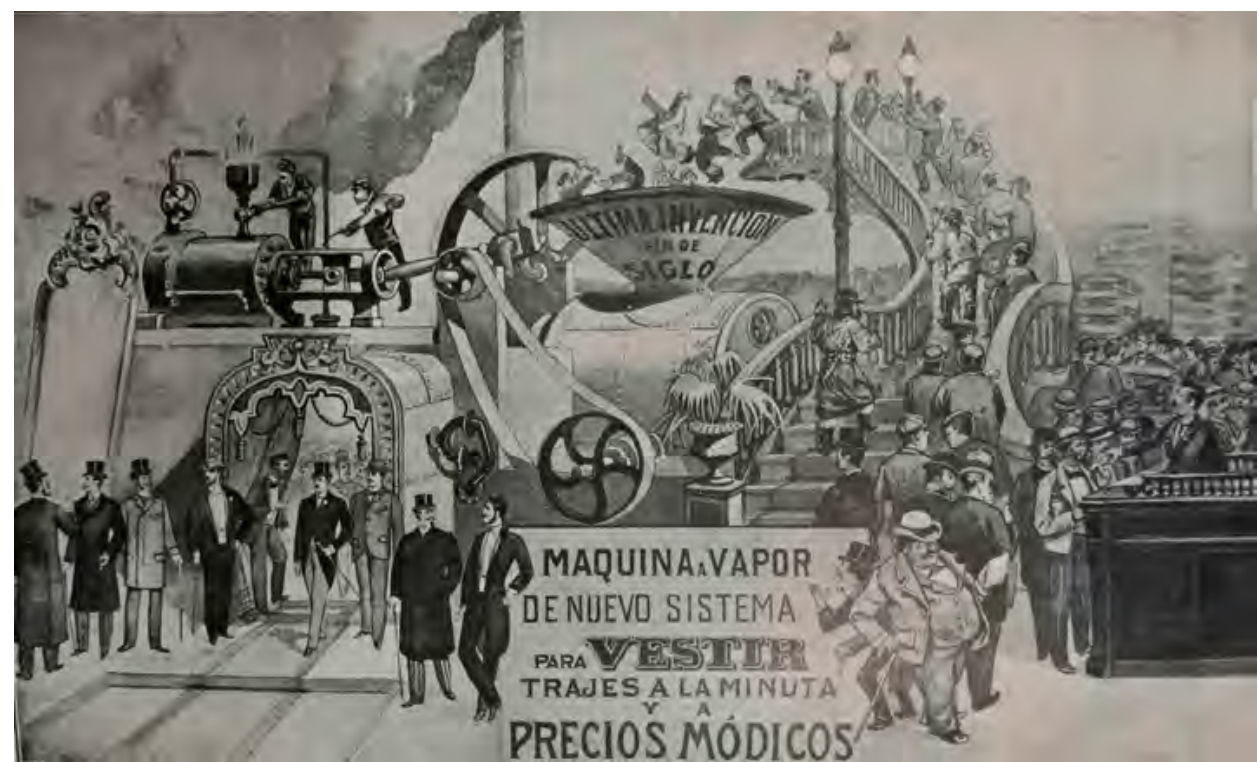

FUENTE: BALDASARRE, María Isabel. Academia Argentina de Letras.

${ }^{23}$ DEMÓCRITO (Eduardo Sojo). Aviso de Palacio de Cristal. La Mujer, año 1, n. 17, 1899. 
Al año siguiente, el proceso parece ya darse por consumado y estos mismos hombres, ahora junto a tres mujeres, protagonizan una publicidad de la misma firma en un parque genérico que no remite a ningún sitio en particular (figura 7). Las siluetas femeninas son acordes con la moda de entonces exhibiendo el característico pecho de paloma, hegemónico a comienzos del siglo gracias al uso de los corsets à la Sirène. Los vestidos ofrecidos por Augusto Schwartz replicaban las imágenes fotográficas que acompañaban el artículo de moda de la misma revista firmado por "Una dama criolla"24. Se reforzaba así el diálogo virtuoso entre figurines y publicidades, aquel que permite considerar a las revistas del siglo XIX como productos "circulares", en los que información construye su potencia y poder de comunicabilidad en el diálogo interno entre las distintas secciones de una misma publicación.

\section{FIGURA 7 - AVISO DE SASTRERÍA LA MODA. ALMANAQUE PEUSER PARA EL AÑO 1900, AÑO 13, BUENOS AIRES, PEUSER, 1899}

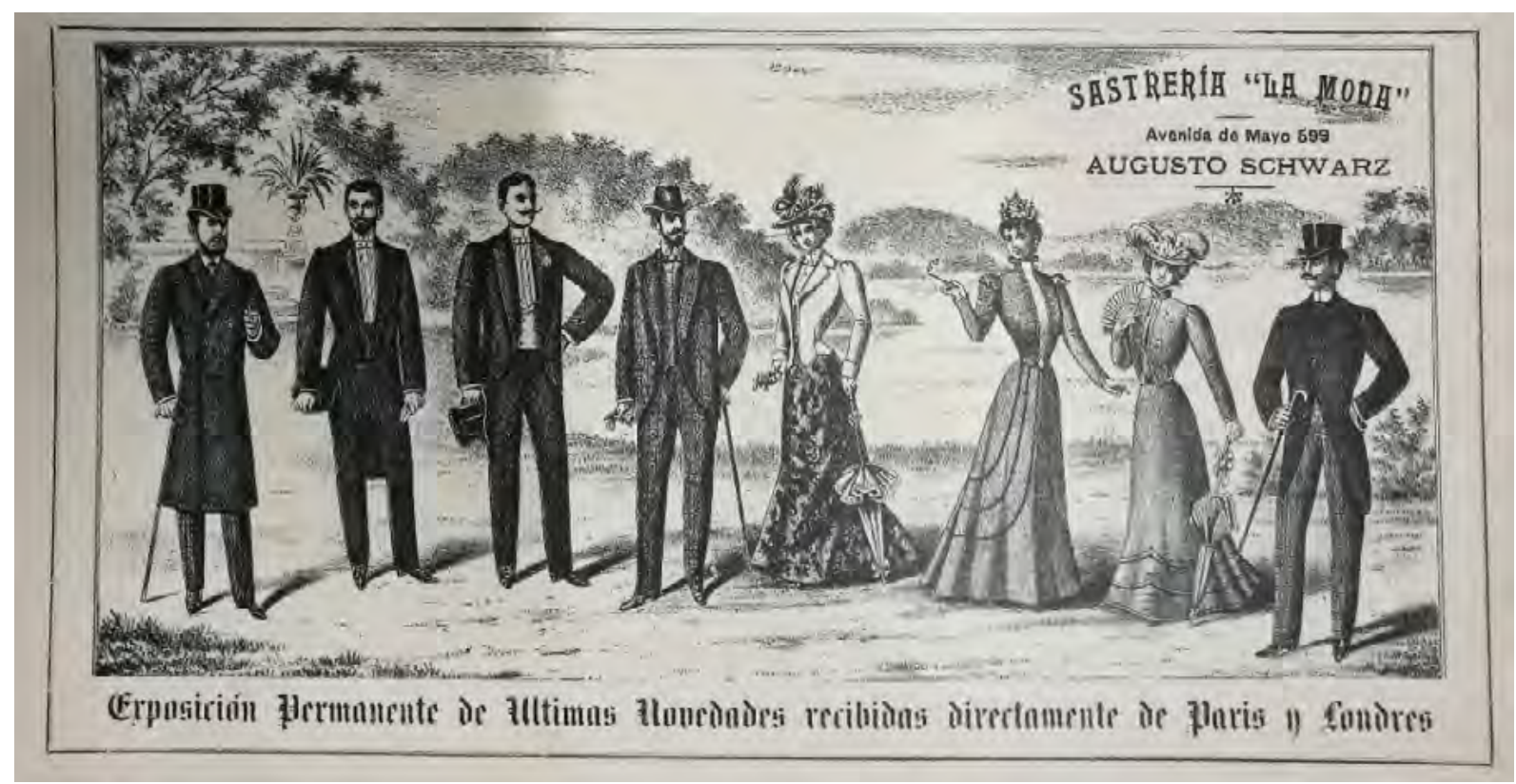

FUENTE: BALDASARRE, María Isabel. Academia Argentina de Letras.

Dentro del panorama de publicidades del período, la más novedosa que hemos hallado (y una verdadera excepción) es la de la Sastrería Brown. Inserta en medio de las páginas monocromas de La Ilustración Sud-Americana dos manos masculinas a color, vistiendo puños impecables, traje y gemelos, actúan como sinécdoque del hombre que apunta en el puño de su camisa que no debe olvidar dejar sus medidas para su sobretodo en lo de Brown (figura 8).

${ }^{24}$ Una dama criolla. Modas. Almanaque Peuser para el año 1900. Buenos Aires: Peuser, 1899, p. 161-165. 

1895

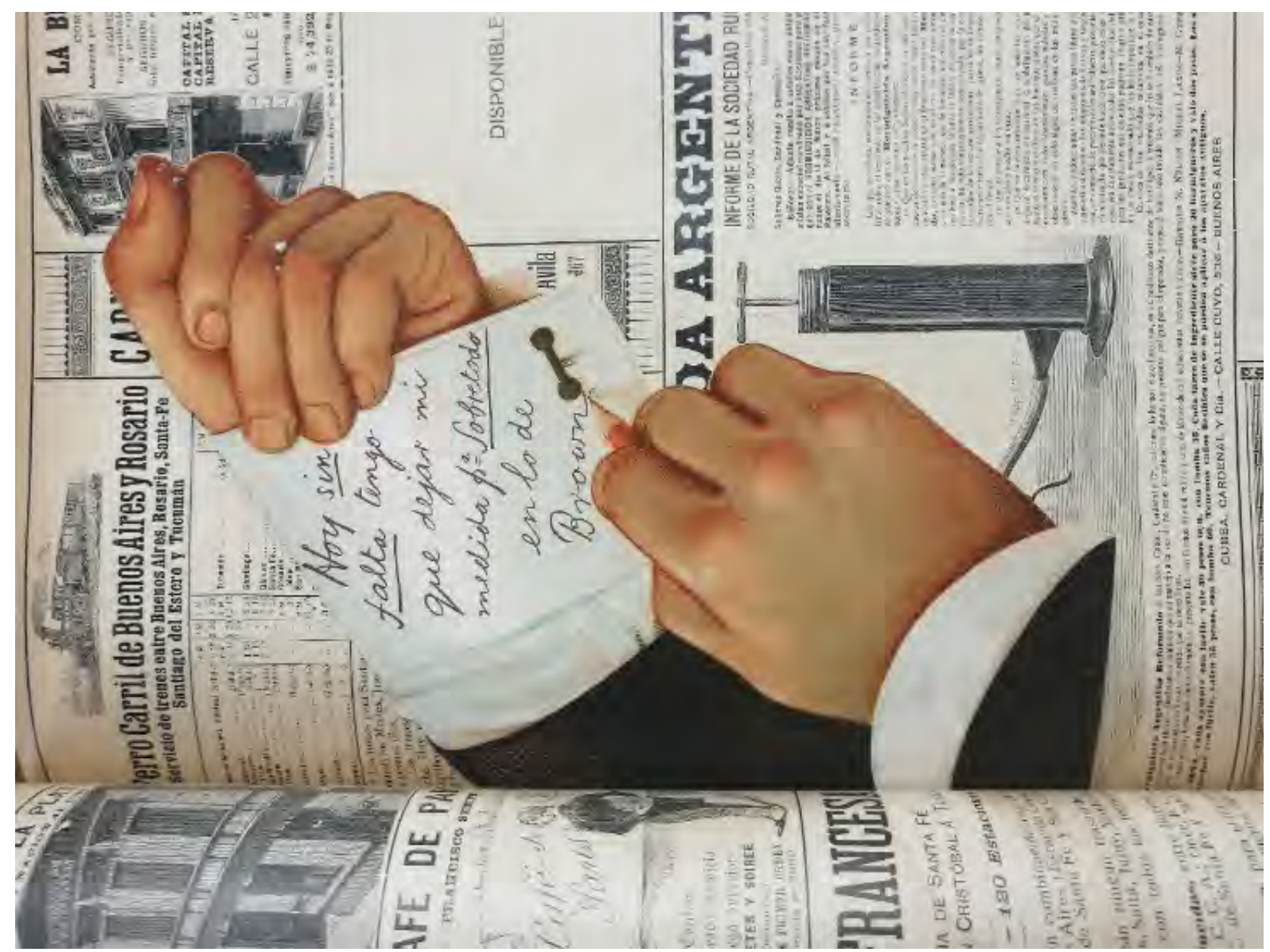

FUENTE: BALDASARRE, María Isabel. Academia Nacional de la Historia.

El recurso a la abstracción fue una de las características usuales de la publicidad del período. Los clichés se transformaron en imágenes globales, carentes de referencias geográficas o sociales específicas, pudiendo funcionar con la misma eficacia en diversos contextos. En general, en los avisos no aparecían indicaciones sobre el modo en que estos trajes y vestidos serían llevados por los hombres y mujeres de la ciudad de Buenos Aires, ni en qué sentido serían re-apropiados por las clases bajas. He aquí uno de los mecanismos reiterados que se observan en las publicidades del fin de siglo: están configuradas como un horizonte de deseo para los sectores altos y medios altos, y en estos términos funcionaban como aspiracionales, aunque no viables de ser llevados a la práctica, por aquellos de menores recursos. Es decir, las imágenes que venimos considerando funcionan en la órbita de lo que Winifred Aldrich postula respecto de la circulación de las revistas de moda y los moldes en la segunda mitad del siglo XIX. Más allá de un acceso ampliado a estos dispositivos, para la mayoría de la población más que una democratización de los estilos de moda lo que se produjo fue la "democratización de un deseo" de posesión de estas ropas y estilos del vestir (ALDRICH, 2003, p. 153). En esta tónica, son raras las publicidades en que los productos hacen parte de las situaciones concretas en que serían utilizados. 
Contamos con algunas excepciones. Por ejemplo, en la publicidad de The New York la propia escena se vuelve pedagógica del nuevo modo de consumir. Haciendo uso de la posibilidad de incorporar reproducciones de fotografías gracias a los procesos del half tone, difundidos en la década de 1890, esta publicidad incluía un fotograbado "retrato fiel de uno de nuestros favorecedores". En esta línea, se exhibía la imagen de un hombre, éste sí con rasgos identificables y no asimilable a un mero maniquí, en el acto de decidir su compra a partir de la visualización del catálogo. Así el aviso informaba a los lectores de todos los pueblos de la República acerca de los nóveles procedimientos de venta y encargo (figura 9).

FIGURA 9 - AVISO DE THE NEW YORK, CARAS Y CARETAS, AÑO 3, N. 88, 9 JUN. 1900

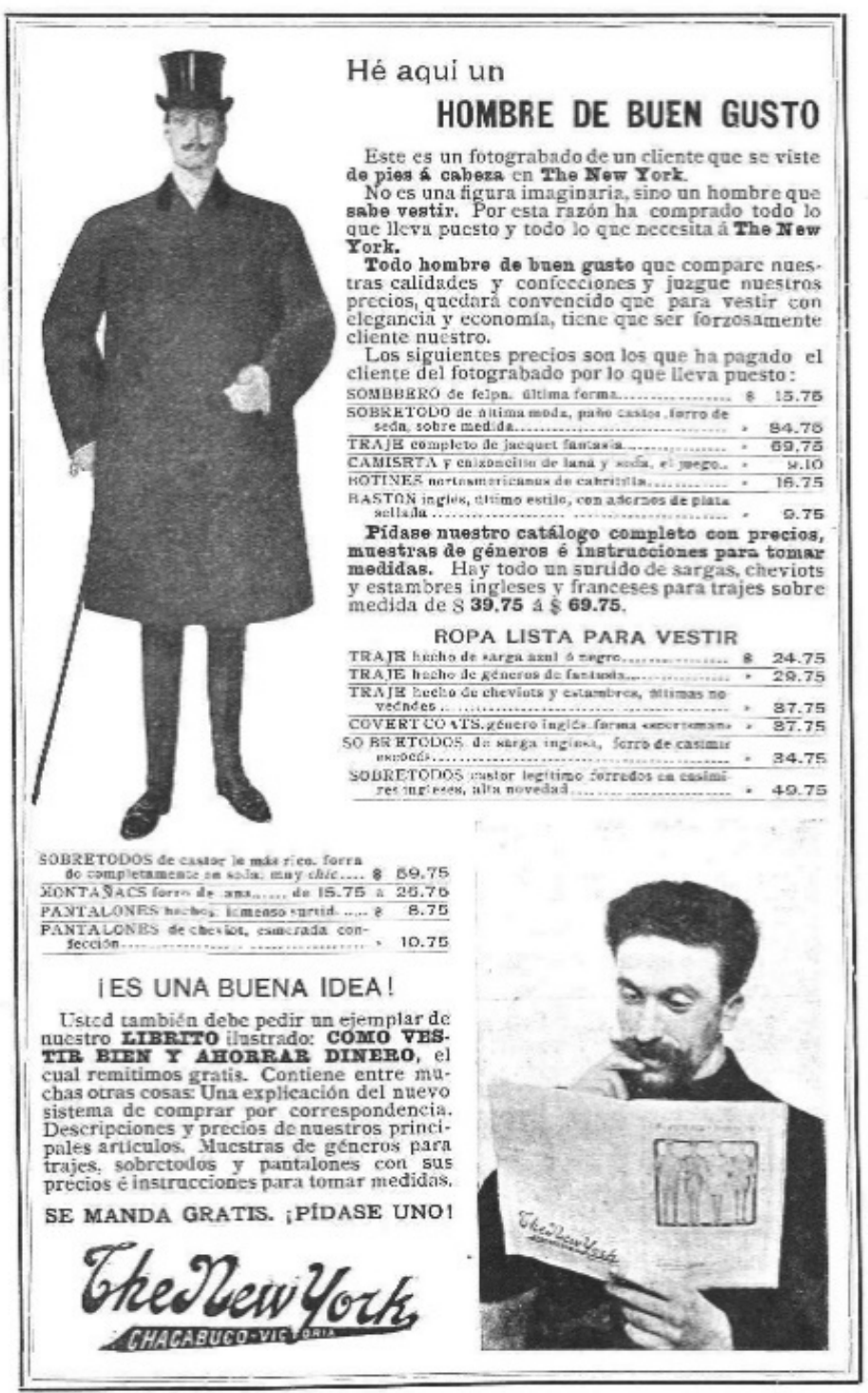

FUENTE: Biblioteca Nacional de España. 


\section{Consumidorxs, clientxs y espectadorxs}

Es complejo definir con certeza al conjunto de consumidores que efectivamente compraban sus productos en los comercios y tiendas mencionadas. No obstante, los precios, analizados en términos comparativos, son índices de la potencialidad de la adquisición de productos por parte de distintos sectores sociales, en un contexto además de alza del salario real y de mejora del poder adquisitivo (CUESTA, 2012). Tomemos por ejemplo los avisos de $A$ la ciudad del Londres y El Progreso publicados en La Ilustración Sud-Americana de 1894. En ellos se anuncia que una jaquette para dama costaba \$28 lo mismo que un traje de saco pantalón y chaleco para niño. Eran valores prohibitivos para un carpintero que tenía un salario promedio de $\$ 3,50$ $\mathrm{m} / \mathrm{n}$ por día (lo que resultaba en $\$ 70 \mathrm{~m} / \mathrm{n}$ por mes) ${ }^{25}$, una empleada doméstica que ganaba entre \$ 45 y \$ 50 mensuales o un cocinero que llegaba a los \$ 75 (BUCHANAN, 1998, p. 239). Se trataba de productos onerosos que apuntaban a comerciantes o profesionales como médicos, contadores o abogados. Sin embargo, los sectores de menores recursos sí podían acceder, en esas mismas tiendas, a otro tipo de artículos “de ocasión”, lo que les permitía, aunque fuera de menor grado, participar en dichos rituales de consumo. Un corte para hacer un vestido en percal costaba $\$ 2,45$, una camisa de madapolán para dama $\$ 1,60$, un sombrero de paja $\$ 0,95$ y un foulard de seda $\$ 0,25$, el equivalente a un kilo de pan en ese entonces. Es lícito pensar en la posibilidad de estas adquisiciones si tenemos en cuenta que aproximadamente un 10\% de la canasta básica de un trabajador se destinaba a la vestimenta (CUESTA, 2012, p. 166).

Por otra parte, la dimensión que estos comercios adquirieron hacia comienzos del siglo nos habla de un público que no se restringía exclusivamente a aquel de altos recursos sino que se expandía para comprender a capas medias y medias bajas. Las liquidaciones, rebajas y ocasiones eran frecuentes al cierre de la saison y, tal como mostraba la prensa, congregaban a una gran cantidad clientes que se agolpaban en la calle esperando el ingreso para comprar ${ }^{26}$. Los repetidos descuentos tenían como objetivo agotar el stock vigente para reproducir la - ya mencionada - lógica de la renovación y la novedad.

Uno de los ítems que más se repiten en la publicidad del período, al punto de "saturar el espacio público de lectura”, fue el corset (SUMMERS, 2001, p. 174). Vendido tanto en comercios de ramos diversos, como por mercerías y corseterías especializadas, el ítem se vinculaba directamente con la erotización de la mercancía y con la transformación de la propia mujer y su belleza en objetos de deseo (BEETHAM, 1996, p. 150). No olvidemos que en ese período las marcas genéricas y la diferencia sexual debían ser manifestadas de forma ostensible en la vestimenta. Justamente la mujer se distinguía por su carácter de artificio construido a partir del vestido, el adorno y los cosméticos (GARB, 1998, p. 115). El poder del corset para alterar el cuerpo era primordial para adecuarlo a los cambios de silueta marcados por los dictados de la moda. Es decir, era una prenda del guardarropa que cambiaba con recurrencia, que implicaba pericia en su fabricación y que con asiduidad aparecía asociada a Francia y a sus corseteras como índice de la calidad y buena realización. Incluso se ofrecían servicios que incluían la confección de la prenda en París, previo envío de las medidas ${ }^{27}$.

\footnotetext{
${ }^{25}$ Los precios están expresados en pesos moneda nacional $(\$ \mathrm{~m} / \mathrm{n})$ que era la moneda de entonces.

26 Véase por ejemplo: Un curioso espectáculo. P.B.T., año 5, n. 171, 22 feb. 1908, p. 79.

27 Aviso de Mon de Vertus Souers, Corseteras, 12 Rue Auber, Paris. El Sud-Americano, año 2, n. 40, 5 marzo 1890.
} 
Hacia 1880 fue frecuente incluir al accesorio desprendido del cuerpo que debía modelar, pero evocándolo al conservar la silueta deseada (figura 10). Esta estrategia visual coincidía, por otra parte, con cómo se exhibía entonces la ropa (interior y exterior) en los comercios: con maniquís sin cabeza que hacían énfasis en el torso. Este modo de representación no despareció en el comienzo del siglo $\mathrm{XX}^{28}$, pero sí convivió con una multiplicidad de imágenes de mujeres en su boudoir, maquillándose, peinándose o mirándose al espejo como excusa para habilitar la presentación de la siempre disruptiva ropa interior. Recordemos que para el siglo XIX las normas de decoro regulaban los usos de estas prendas, las cuales en general eran escondidas de la vista pública. De hecho, los eufemismos llevaban a evitar la palabra interior para referirla como "ropa blanca". Esencialmente íntima, no podía desprenderse del vínculo directo con el cuerpo desnudo al que daba forma o disimulaba, ni de los espacios privados en que podía ser mostrada (PERROT, 1996, p. 143). El cuerpo encorsetado era un cuerpo desnudo. No sorprende entonces que se optara por ilustraciones por sobre fotografías de mujeres reales a la hora de reproducir estos indumentos ${ }^{29}$.

\section{FIGURA 10 - AVISO DE A LA CIUDAD DE LONDRES. CORSÉ CORAZA, LA FAMILIA, PERIÓDICO ILUSTRADO, 5 MAYO 1878}

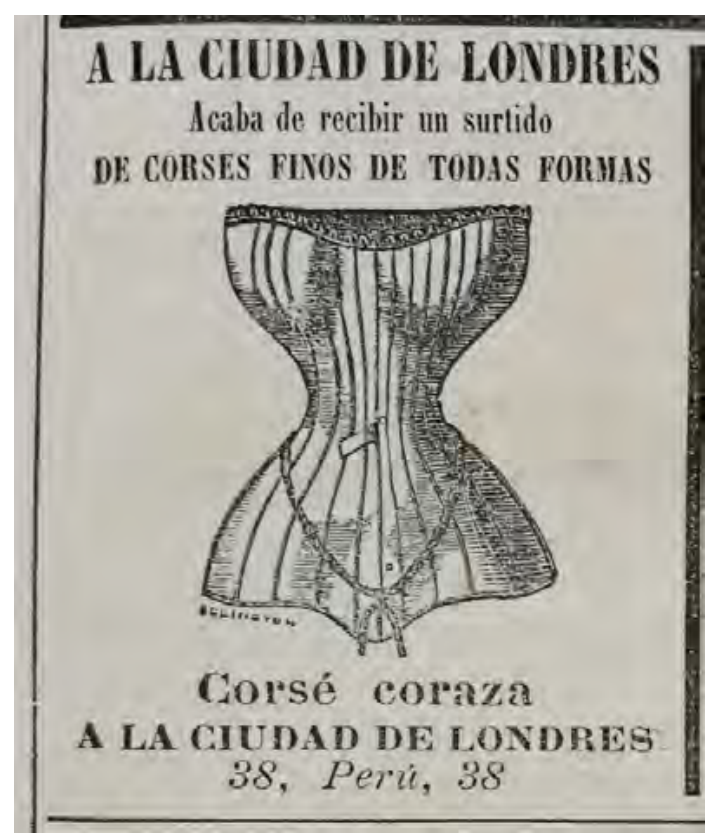

FUENTE: BALDASARRE, María Isabel. Academia Argentina de Letras.

A tono con los cambios en la silueta, la tienda A la Ciudad de México se ufanaba de ser la única de ofrecer los corsets "C. P. Sirène" aunque las publicidades nos dan a entender que había otros comercios que vendían precisamente ese mismo tipo de corset que aseguraba "la respiración franca, el desarrollo del pecho y la facilidad de movimiento".

\footnotetext{
${ }^{28}$ Véase por ejemplo aviso de Corsetería La Elegancia Porteña. Caras y Caretas, n. 136,11 mayo 1901.

29 Recién encontramos fotografías de mujeres vistiendo corsets en las publicidades de comienzos de la década de 1920 .
} 
Las publicidades también nos dan indicios de los modos en que, quiénes no disponían de recursos suficientes, podían ingeniárselas para no renunciar a los mecanismos para la modelación corporal. Se anunciaban productos que podían contribuir a que las consumidoras realizasen ellas mismas el emballenado de sus prendas como por ejemplo Featherbone, útil para "emballenar su bata á máquina empleando la cuarta parte del tiempo que necesitaría para colocar ballenas comunes" ${ }^{30}$. Los avisos además instalaban su propia pedagogía como sucedía con las imágenes que desplegaban las distintas maneras de atar o prender el corset ${ }^{31}$.

Para comienzos del siglo XX, los avisos de corsets fueron construcciones sofisticadas que dieron rienda suelta a las fantasías hedonistas de las clases medias urbanas. Por ejemplo, la publicidad de 1904 de A la Ciudad de México recurre al imaginario del gineceo: en el boudoir de una casa burguesa cuatro muchachas se regodean en el acto de ajustarse sus corsets "A la Sirène" por sobre sus enaguas y sus chemises (figura 11). La entrega a la contemplación, propia y de sus pares, se hace extensiva al espectador que es interpelado por la joven del centro que, con indolencia, tuerce su cabeza y orienta sus ojos para reforzar el pacto escópico implicado en el placer de mirar. La imagen refería, sin citarlo de modo explícito, a todo un repertorio de representaciones femeninas recurrentes en el arte del período, desde la "ninfa de la espalda quebrada" a la "circularidad urobórica de la mujer" reflejada en el espejo y en la ronda de pares (DIJKSTRA, 1994). Para potenciar el atractivo comercial del producto se recurría a una síntesis de varios tópicos del erotismo: de la iconografía del burdel a las alusiones al homoerotismo femenino.

\section{FIGURA 11 - AVISO DE A LA CIUDAD DE MÉXICO. CORSÉS C. P. A LA SIRÈNE, CARAS Y CARETAS, AÑO 7, N. 284, 12 MARZO 1904}

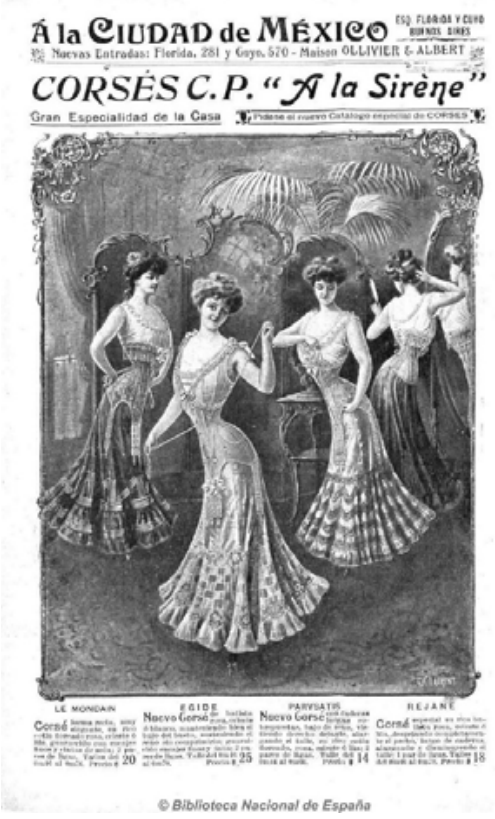

FUENTE: Biblioteca Nacional de España.

\footnotetext{
30 Aviso de Featherbone. La Mujer, n. 38, 19 oct. 1900.

${ }^{31}$ Aviso de A la Ciudad de México. Caras y Caretas, 3 jun. 1905.
} 
De este modo, a medida que las publicidades se volvieron más complejas hicieron uso de, pero también contribuyeron a, cimentar las ideas de placer entre consumidores y consumidoras. Una idea que claramente, descansaba en presupuestos de clase, etarios y de género en los que la mirada masculina fue fundamental, en tanto eran mayormente hombres quiénes producían estas representaciones.

\section{Consideraciones finales}

El pacto que se forjó entre moda, novedad y publicidad hacia fines del siglo XIX en estas ciudades nuevas pero pujantes como Buenos Aires fue ineludible. Fue la manera de hacer propias las pautas del consumo moderno fijadas por capitales como París y Londres. Las tiendas fluctuaron entre reproducir clichés europeos sin demasiadas adaptaciones para el público porteño, o por el contrario tratar de adecuarlos mediante referencias verbales o espaciales a las características particulares de los habitantes de la ciudad. En todos los casos, la retórica de lo nuevo, la variedad, lo importado fueron elementos centrales a la hora de estimular el consumo de indumentaria dentro de lo que podríamos considerar una visualidad gráfica global extendida desde mediados del siglo XIX en casi todas las urbes del hemisferio occidental.

El proceso de difusión de estos parámetros fue homogéneo y exitoso. Buenos Aires participó de la instalación de las grandes tiendas y del desarrollo publicitario sin proponer grandes alteraciones, aunque sí lo hizo en un lapso corto de tiempo con una intensidad y volumen significativos. Las singularidades del caso local tienen más que ver con la coyuntura del momento en que estas publicidades y mecanismos de consumo adquirieron verdadera escala masiva.

En Europa este proceso de oferta y acceso extensivo a los productos, mediante la publicidad, instaló la idea de un "sueño democrático". A diferencia de la anterior sociedad aristocrática, más restrictiva, ahora todos (entendiendo en este todos fundamentalmente a las clases medias) podrían ser consumidores. En capitales como la argentina, cuyas capas medias se estaban formando al ritmo del crecimiento urbano estas dinámicas se dieron en simultáneo. Así, ser un porteño o porteña, o un inmigrante recién llegado, que aspiraba a integrarse a la vida metropolitana en el siglo XIX estaría indefectiblemente asociado con la posibilidad de gozar de algunos de estos productos de vestimenta y adorno vueltos deseables por la publicidad moderna. Si no era posible adquirirlos, las tiendas también ofrecían los modos para replicarlos domésticamente y garantizar, cuanto menos en forma parcial, el cumplimiento del sueño del consumo y la transformación del comprador en cliente. 


\section{Referencias}

Álbum ilustrado de la República Argentina. Periódico quincenal con vistas y retratos, Buenos Aires, 1891.

Almanaque para la familia. Modas y novelas ilustradas, Buenos aires, F. Lajoune éditeur, 1880.

Almanaque Peuser, Buenos Aires, Peuser, 1897-1899.

ALDRICH, Winifred. The impact of fashion on the cutting practices for the woman's tailored jacket 1800-1927. Textile History. 2. ed. V. 34, p. 134-170, 2003. Disponible en: https://doi. org/10.1179/004049603235001580. Acceso en: abril 2019.

BEETHAM, Margaret. A magazine of her own? Domesticity and desire in the woman's magazine, 1800-1914. London: Routledge, 1996.

BREA, José Luis. Estética, historia del arte, estudios visuales. Estudios Visuales. N. 3, enero de 2006.

BUCHANAM, William I. La moneda y la vida en la República Argentina. Salarios: 1886 a 1896. Cuadernos del CISH, año 3, n. 4, p. 239-256, 1998.

Caras y Caretas: semanario festivo, literario, artístico y de actualidades, Buenos Aires, 1898-1941

CUESTA, Martín E. Precios y salarios en Buenos Aires durante la gran expansión (18501914) Revista de Instituciones, ideas y mercados, n. 56, p. 159-179, mayo 2012.

DIJKSTRA, Bram. Ídolos de perversidad. La imagen de la mujer en la cultura de fin de siglo. Madrid: Debate, 1994.

DUSSAILLANT CHRISTIE, Jacqueline. Las reinas de Estado: consumo, grandes tiendas y mujeres en la modernización del comercio de Santiago (1880-1930). Santiago: Universidad Católica de Chile, 2011.

El Hogar. Ilustración semanal argentina, Buenos Aires, 1904-1963.

El Mosquito. Periódico semanal, independiente, satírico, burlesco y de caricatura, Buenos Aires, 1863-1893.

GALARCE, A. Bosquejo de Buenos Aires capital de la nación Argentina. Buenos Aires: Imprenta, Litografía y Encuadernación de Stiller \& Laass, tomo II, 1887.

GARB, Tamar. Bodies of modernity: figure and flesh in fin-de-siècle France. London: Thames and Hudson, 1998. 
GORBERG, Marissa. Parc Royal: um magazine na belle époque carioca. Rio de Janeiro: G. Ermakoff, 2013.

Gran guía general comercial de la República Argentina. Estadística, Agricultura, Administración 1878-1879, Buenos Aires, M. S. Bagley y Ca.

GUY, Donna J. Comprar, comer y socializar en la calle Florida entre 1914 y 1920. En: HALLSTEAD, Susan R.; ROOT, Regina A. (comps.). Pasado de moda: expresiones culturales y consumo en la Argentina. Buenos Aires: Ampersand, 2017.

La Familia. Periódico semanal para todos, Buenos Aires, 1878-1879.

La Ilustración Sud-Americana, Buenos Aires, 1892-1915.

La Mujer. Álbum revista, Buenos Aires, 1899-1901.

LLOYD, Reginald (dir.). Impresiones de la República Argentina en el Siglo Veinte. Su historia, gente, comercio, industria y riqueza. Londres: Lloyds Greater Britain Publishing Company, 1911.

LOEB, Lori Anne. Consuming Angels. Advertising and Victorian Women. New York: Oxford University Press, 1994.

MANSILLA, Lucio V. Entre-nos. Causeries del jueves. Buenos Aires: Casa Editora de Juan A. Alsina, 1890, tomo V.

MARTÍNEZ, Alberto B. Manual del viajero. Baedeker de la República Argentina. Buenos Aires: Imprenta, Litografía y Encuad. de Jacobo Peuser, 1904, 2. edición.

MILLER, Michael Barry. The Bon Marché: bourgeois culture and the department store, 1869-1920. Princeton: Princeton University Press,1981.

MIRZOEFF, Nicholas. Una introducción a la cultura visual. Barcelona: Paidós, 2003.

MITCHELL, William John Thomas. El giro pictorial. En: Teoría de la imagen. Ensayos sobre representación verbal y visual. Madrid: Akal, 2009, p. 19-38.

MOREYRA, Cecilia; GARABANA, Teresita. 'Baratura y clase'. El discurso publicitario de la tienda a la ciudad de Londres en la prensa gráfica. Buenos Aires hacia fines del siglo XIX. Trashumante. Enero de 2019. Disponible en: https://doi.org/10.17533/udea.trahs. n13a01. Acceso en: junio 2019. 
MOXEY, Keith. Nostalgia de lo real. La problemática relación de la historia del arte con los estudios visuales. Estudios Visuales, n. 1, noviembre de 2003.

MUNILLA LACASA, María Lía; GLUZMAN, Georgina G. Imágenes globales/selecciones locales: las publicaciones periódicas europeas en los diarios porteños. El caso de El Recopilador y Andrea Macaire. En: SZIR, Sandra (coord.). Ilustrar e imprimir. Una historia de la cultura gráfica en Buenos Aires, 1830-1930. Buenos Aires: Ampersand, 2016, p. 23-52.

MALOSETTI COSTA, Laura; GENÉ, Marcela (comps.). Impresiones porteñas. Imagen y palabra en la historia cultura de Buenos Aires. Buenos Aires: Edhasa, 2009.

NELSON BEST, Kate. The history of fashion journalism. London/New York: Bloomsbury, 2017.

PERROT, Philippe. Fashioning the bourgeoisie. A history of clothing in the Nineteenth Century. Princeton: Princeton University Press, 1994.

RAPPAPORT, Erika Diane. Shopping for pleasure: women in the making of London's West End. Princeton: Princeton University Press, 2001.

ROCCHI, Fernando. Chimneys in the desert: Argentina during the export boom years, 1870-1930. London: Stanford University Press, 2006.

ROMÁN, Claudia. Prensa, política y cultural visual. El Mosquito (Buenos Aires, 18631893). Buenos Aires: Ampersand, 2017.

STEELE, Valerie. Paris fashion: a cultural history. New York: Berg, 1998.

SUMMERS, Leigh. Bound to please: a history of the victorian corset. New York: Berg, 2001.

SZIR, Sandra M. Discursos, prácticas y formas culturales de lo visual. Buenos Aires 1880-1910. En: BALDASARRE, María Isabel; DOLINKO, Silvia (eds.). Travesías de la imagen. Historias de las artes visuales en la Argentina. Buenos Aires: CAIA-EDUNTREF, 2011, p. 65-93. 